\title{
PEMEROLEHAN BAHASA PERTAMA MELALUI PIVOT GRAMMAR
}

\author{
Syahfitri Purnama \\ Fakultas Pendidikan Bahasa \\ Universitas Indraprasta PGRI, Jakarta \\ Pos-el: syahfitripurnama@gmail.com
}

\begin{abstract}
The purpose of this study was to assess the child's first language syntax acquisition two years of age through the pivot grammar. The first source of this research is Francesca Sophia, Superkids student, Kemang, South Jakarta. This research used descriptive analysis and data collected, captured, recorded, transcribed, and analyzed. The results of this study are: (1) language acquisition is a very long process since the children do not know a language, (2) the family is needed in the development of their language (3) At the age of two years children have been able to produce pivot grammar, phrase and simple sentence (4) A child could use a negative form, structure modification consisting of a possessive phrase, descriptive phrases, and deixis.
\end{abstract}

Keywords: first language acquisition, pivot grammar, Speech production development

\begin{abstract}
ABSTRAK
Tujuan penelitian ini adalah untuk mengkaji pemerolehan sintaksis bahasa pertama anak umur dua tahun yakni bahasa Inggeris melalui pivot grammar. Sumber pertama penelitian ini adalah siswa sekolah Superkids, Kemang, Jakarta Selatan yang bernama Francesca Sophia. Penelitian ini adalah penelitian deskriptif analisis dan data dikumpulkan, diambil, direkam, ditranskripsikan, dan dianalisis. Hasil penelitian ini adalah: (1) pemerolehan bahasa merupakan sebuah proses yang sangat panjang sejak anak belum mengenal sebuah bahasa sampai fasih berbahasa, (2) keluarga diperlukan dalam pengembangan bahasa mereka (3) Pada umur dua tahun anak telah mampu menghasilkan ujaran dua kata (pivot grammar), frasa, dan kalimat sederhana (4) Anak telah mampu membuat bentuk negatif, struktur modifikasi yang terdiri dari frasa posesif, frasa deskriptif, dan deiksis.
\end{abstract}

Kata Kunci: pemerolehan bahasa anak, ujaran dua kata, pengembangan produksi wicara

\section{PENDAHULUAN}

Istilah pemerolehan bahasa (language acquisition) diartikan sebagai proses pemerolehan bahasa yang dilakukan oleh anak secara natural pada waktu ia belajar bahasa ibunya (native language) (Dardjowidjoyo, 2005:225), sedangkan pembelajaran diartikan sebagai proses yang dilakukan dalam tatanan yang formal, yakni belajar di kelas dan diajar oleh seorang guru. Oleh karena itu proses anak yang belajar menguasai bahasa ibunya adalah pemerolehan, sedangkan proses dari orang dewasa yang belajar di kelas adalah pembelajaran. Chaer (2002:167) mengatakan bahwa pemerolehan bahasa atau akuisisi bahasa adalah proses yang berlangsung di dalam otak seorang anak ketika dia memperoleh bahasa pertamanya atau bahasa ibunya.

Salah satu faktor yang berkaitan dengan proses pemerolehan bahasa pertama pada seorang anak yaitu faktor lingkungan kehidupan sehari-hari anak tersebut, seperti yang dinyatakan oleh Skinner (dalam Dardjowidjojo, 2005: 235) bahwa pemerolehan bahasa pertama pada seorang anak dipengaruhi oleh kehidupan lingkungan di sekitarnya. Hal ini karena lingkungan keluarga merupakan lingkungan yang paling dekat dengan dengan kehidupan anak, sehingga anak akan belajar bahasa dari keluarga. Disamping 
itu adanya kebutuhan dan motivasi yang bersifat eksternal yaitu keinginan berinteraksi dengan orang lain menjadi faktor dalam proses belajar bahasa pertama (Mukalel, 2003:16).

Pandangan tersebut mengisyaratkan bahwa bahasa sehari-hari yang digunakan keluarga dalam berkomunikasi dengan anak menjadi bahasa ibu pada anak tersebut. Bahasa pertama yang akan diperoleh oleh anak yaitu bahasa sehari-hari yang digunakan oleh keluarga. Chomsky (dalam Dardjowidjojo, 2005: 236) mengatakan bahwa masukan berupa bahasa akan menentukan bahasa yang akan dikuasai anak. Misalnya bahasa yang akan digunakan oleh orang tua untuk berkomunikasi dengan anak yang masih berusia dini tidak menutup kemungkinan menjadi bahasa pertama yang akan dikuasainya.

Dua proses yang terjadi ketika seorang anak sedang memperoleh bahasa pertamanya, yaitu proses kompetensi dan proses performansi. Kedua proses ini merupakan dua proses yang berlainan. Kompetensi adalah proses penguasaan tata bahasa yang berlangsung secara tidak disadari. Proses kompetensi ini menjadi syarat untuk terjadinya penerbitan atau proses yang terdiri dari dua buah proses, yaitu proses pemahaman dan proses penerbitan atau proses menghasilkan kalimat-kalimat. Proses pemahaman melibatkan kemampuan atau kepandaian mengamati atau kemampuan mempersepsi kalimat-kalimat sendiri. Kedua jenis proses kompetensi ini jika telah dikuasai seorang anak akan menjadi kemampuan memahami dan kemampuan melahirkan atau menerbitkan kalimat-kalimat baru yang dalam linguistik transformasi generatif disebut perlakuan, atau pelaksanaan bahasa atau performansi.

Di dalam penelitian ini difokukan pada pemerolehan sintaksis bahasa pertama yakni bahasa Inggris melalui pivot grammar anak umur dua tahun, Francesca Sophia, siswa sekolah Superkids, Kemang, Jakarta Selatan yang tinggal di Jakarta mengikuti kedua orang tuanya bekerja. Pada saat Francess berumur 1 tahun 8 bulan. Data yang digunakan diambil, direkam dan ditranskripsikan secara alamiah ketika Francesca sedang bermain-main di rumah bersama ibu, kakak, dan pengasuhnya pada tahun 2006.

\section{Rumusan Masalah}

Rumusan masalah penelitian ini adaalah sebagai berikut.

1. Bagaimanakah proses pemerolehan bahasa anak umur dua tahun.

2. Apa yang sudah diperolehnya pada umur dua tahun.

\section{Tujuan Penelitian}

Peneliian ini bertujuan untuk mengetahui proses pemerolehan bahasa anak umur dua tahun.

\section{Landasan Teori Bahasa Universal}

Anak memperoleh bahasa secara alami di dalam keluarga. Menurut Chomsky (1994: 34) dalam Dardjowidjojo (2000:19) manusia memiliki faculties of the mind, yakni sejenis kapling-kapling intelektual yang ada dalam otak mereka. Salah satu dari kapling-kapling itu adalah pemerolehan bahasa. Pemerolehan Bahasa (Language Acquisition Device) yang dimiliki anak dapat berkembang, ia sebenarnya bukan suatu proses yang dilakukan oleh, tetapi yang terjadi pada anak. Caranya proses itu terjadi, waktunya, dan rincian-rincian lainnya memang itu sendiri pada esensinya "inner directed". Menurut Chomsky (1999: 41):

Language learning is not really something that the child does, it is something that happens to the child placed in the appropriate environment, much as the child's body grows and matures in predetermined way when provided with appropriate nutrition and environmental stimulation.

Anak juga akan belajar bahasa dari pengalamannya berkomunikasi dengan orang dewasa. Ketika terjadi proses komunikasi, kadang-kadang orang dewasa berbicara menggunakan struktur bahasa yang kurang baik, mungkin karena pikirannya sedang terbagi ketika berbicara, tetapi hal ini tidak akan membuat anak mengikuti yang salah karena disaring oleh piranti Pemerolehan Bahasa. 


\section{Pemerolehan Bahasa}

Dari berbagai macam keuniversalan serta proses pemerolehan seperti yang baru saja digambarkan tampak bahwa pemerolehan bahasa seorang anak berkaitan erat dengan keuniversalan bahasa. Urutan pemerolehannya bersifat universal absolut, ada yang universal statistikal, dan ada pula yang universal implikasional. Bahkan keterkaitan ini lebih menjurus lagi dalam arti bahwa ada elemen-elemen bahasa yang mana masuk kelompok mana tampaknya tergantung pada macam komponen yang terlibat. Dalam komponen fonologi, misalnya, sifat keabsolutannya sangat tampak dalam arti bahwa suatu bunyi tidak mungkin dikuasai anak sebelum bunyi lain, meskipun kendala seperti ini tidak berlaku untuk seluruh bunyi pada bahasa tersebut. Dalam komponen sintaktik kecendrungan untuk bersifat absolut tampaknya kurang kuat, sedangkan dalam komponen semantik kecendrungan untuk bersifat universal ini sangat tipis (Dardjowidjoyo, 2000: 21)

\section{Keuniversalan dan Pemerolehan Sintaksis}

Sistem dasar dan pertama yang akan diterima anak dalam pemerolehan bahasa adalah fonologi bahasa (Mukalel, 2000: 21). Kemudian berlanjut dengan memproduksi bunyi yang anak dengar ketika orang dewasa berbicara. Misalnya kata"uncle" diucapkan anak dengan "unc" "milk" dengan "mik" Ini adalah proses belajar kata (Mukalel, 2000: 23). Pada komponen sintaksis, orang tidak dapat dengan mudah memaparkan secara rinci dan tepat (serta berani) apa yang persisnya terjadi pada diri anak dalam menguasai sintaksis suatu bahasa. Di samping titik pandang serta aliran keilmuan yang berbeda-beda, masalah yang dihadapi memang bukan masalah yang banyak kaitannya dengan neurobiologi manusia seperti halnya pada komponen fonologi. Dalam komponen fonologi, orang dapat secara lebih tepat dan berani mengatakan apa yang akan terjadi pada diri manusia sangat ditentukan oleh kondisi biologis serta neurologis manusia, tetapi tidak pada komponen sintaksis (Dardjowidjojo, 2000: 25).

Dalam bidang sintaksis anak mulai dengan ujaran satu kata (one word utterance), kemudian ujaran dua kata (two utterances), dan akhirnya ujaran tiga dan multi kata. Meskipun ujaran satu kata secara sintaksis sangat sederhana, secara sistematis ujaran ini bermulti arah karena makna dari ujaran tersebut hanya dapat ditafsirkan sesuai dengan situasi yang ada, dan itu pun belum tentu bermakna tunggal. Bila seorang anak mengatakan kata "water, go, me atau mama dalam situasi kontekstual akan diartikan oleh ibu yang selalu dekat dengan anak sebagai): I need water (saya mau minum), You go away from me (Kamu pergi dari dariku), give me the doll (mau boneka), hold me in your arms, mama (mau gendong, mama) (Mukalel, 2003: 25).

Interpretasi ini menjadi agak mudah setelah anak masuk ke tahap ujaran dua kata karena paling tidak kita mempunyai indikator yang bertalian. Pada umumnya kata-kata dalam tahap ini merujuk pada kasus serta perbuatan atau proses yang dinyatakan oleh kedua kata tersebut. Dengan demikian makna dapat terjadi kombinasi seperti (a) pelaku-penderita, (b) perbuatan-penderita, (c) pelaku-perbuatan, (d) proses-penderita, (e) penderita-lokasi, dan (f) pelaku-lokasi. Setelah ujaran dua kata, anak pada umumnya mulai dengan ujaran tiga kata atau lebih. Namun perlu dicatat bahwa batas antara satu tahap dengan tahap lain sangat relatif sehingga yang sering terjadi adalah bahwa anak masuk ke suatu tahap dengan masih bersandar banyak pada tahap sebelumnya.

Bentuk-bentuk kalimat yang rumit, seperti sematan tengah (center embedding), dikuasai lebih belakangan dibandingkan dengan peluasan belakang (right hand embeding) karena anak pada umumnya menghindari konstruksi yang memisahkan dua elemen yang seharusnya berdekatan. Pemisahan subjek dari predikatnya dengan menyematkan anak kalimat di tengahnya seolah-olah membuat urutan berpikir anak menjadi semacam terputus. Begitu juga bila ada dua peristiwa yang terjadi berurutan, anak cenderung unutk menempatkan peristiwa pertama pada awal kalimat dan peristiwa kedua pada akhir kalimat. Dengan tahap mental yang masih seperti ini keempat kalimat berikut semuanya dianggap memiliki makna yang sama oleh anak.

(1) The dog came after the cat left.

(2) After the dog came, the cat left.

(3) The cat left before the dog came.

(4) Before the dog cam, the cat left. 
Dalam teori Miller yang dinamakan theory of derivational complexity dinyatakan bahwa urutan produksi kalimat anak ditentukan oleh banyaknya derivasi yang harus dilalui. Jadi semakin banyak derivasinya, maka semakin belakangan digunakan oleh anak.. Dengan demikian kalimat Didn't they have to go pasti dikuasai lebih belakangan daripada Did they have to go atau They did not have to go. Dalam bidang morfologi ada pula kencendrungan bagi anak untuk memperoleh afiks infleksional lebih awal daripada afik derivasional (Peters, 1995). Demikian pula afiks yang mempunyai bentuk dan makna yang ajeg umumnya dikuasai lebih awal daripada afiks-afiks lainnya yang bentuk atau maknanya sering berubah. Disamping itu, sufiks umumnya dikuasai lebih awal daripada prefiks (Kuczajm 1979; Hawkins, 1992 dalam Dardjowidjojo, 2000: 25--28)

\section{Pengembangan Produksi Wicara}

Ada beberapa tahap pemerolehan bahasa anak, yaitu: 1) tahap pengocehan (babling), 2) tahap satu kata (holo-phrastic), 3) tahap dua kata (one phrase), dan 4) tahap menyerupai telegram (telegraphic speech) (Steinberg,1993: 3--9)

\section{Tahap Pengocehan (babbling stage)}

Bila seorang anak sampai pada usia enam bulan, ia mulai mengeluarkan suara ocehan. Dalam tahap ini anak sudah dapat mengucapkan sejumlah bunyi ujaran yang sebagian besar tidak bermakna dan sebagian kecil menyerupai kata atau penggalan kata yang bermakna karena kebetulan saja. Tahap ini penting artinya karena dalam tahap ini anak belajar menggunakan bunyi-bunyi yang benar yang dapat diterima orang sekelilingnya dan ia mulai menirukan pola-pola intonasi kalimat-kalimat yang diucapkan oleh orang dewasa. Babbling adalah sejenis tipe vokalisasi dimana anak menggunakan bunyi-bunyi ujaran, seperti vokal dan konsonan-vokal silabel, contohnya "a, u, ma, gi, pa". Ujaran ini bermakna "mama, gigi, papa"

\section{Tahap Satu Kata atau Tahap Holofrastik (the one-word or holophrastic stage)}

Pada sekitar satu tahun seorang anak mulai menggunakan serangkaian bunyi berulang -ulang untuk makna yang sama. Pada usia ini anak sudah mengerti bahwa bunyi ujaran berkaitan dengan makna dan mulai mengucapkan kata-kata pertama. Tahap ini dinamakan tahap satu kata sama dengan satu frasa atau kalimat, yang berarti bahwa satu kata yang diucapkan anak merupakan satu konsep yang jelas. Contoh, kata food, clothing, vehicles, animals. Slobin (1973:79) mengatakan bahwa seorang anak sulit merangkai kata dalam kalimat, jadi orang tua harus menginterpretasiaknnya sesuai dengan konteknya. Misalnya, bila seorang anak mengatakan kata "daddy" sambil menunjuk foto ayahnya berarti fungsi ujaran itu menamakan "ayah", tetapi bila ujaran itu dilakukannya sambil menunjuk sandal ayahnya, makna kata ini berhubungan dengan hak milik antara ayah dan objek tanpa menamakan objek ("sandal").

\section{Tahap Dua Kata}

Pada kira-kira menjelang usia dua tahun, seorang anak mulai mengucapkan ujaran-ujaran yang terdiri dari dua kata. Dalam tahap ini anak menggunakan rangkaian dua kata yaitu pivot dan open.

Menurut Longman Dictionary (2002: 402), pivot grammar adalah sebuah istilah yang berhubungan dengan perkembangan gramatikal anak didalam pembelajaran bahasa pertamanya. Anakanak mengembangkan dua kelas kata gramatikal mayornya yaitu kelas "pivot", contoh kata on, allgone, more dan "open class", contoh, shoe, milk, book. Jadi pivot grammar merupakan perpaduan kedua kata itu. Pivot grammar ini sama denga ujaran dua kata. Sejalan dengan usianya, anak sudah dapat menggunakan bahasa meminta, mengingatkan, menolak, menjawab, dan menginformasikan (Steinberg,1993 7). Anak juga telah mampu menggabungkan dua kata dengan harapan pendengar akan mengerti hubungan ujaran dua kata, seperti "banana table" yang berarti "The banana is on the table"

Braine (1963) mengatakan pemakaian Pivot grammar yang digunakan anak tidak sama dengan grammar orang dewasa, tetapi secara relatif bersifat konsisten. Bentuk pivot grammar ini dilakukan anak berumur 18-24 bulan. Umumnya kata benda dan ajektif pivot muncul pada awal pivot, sedangkan kata kerja muncul setelah akhir pivot. Di bawah ini diperlihatka tabel pivot grammar. 
Tabel PIVOT GRAMMAR

\begin{tabular}{|l|l|}
\hline \multicolumn{1}{|c|}{ Pivot-Class Word } & \multicolumn{1}{|c|}{ Open-Class Word } \\
\hline All (quantity) & \multicolumn{1}{|c|}{$\begin{array}{l}\text { Broke, buttoned, clean, done, dressed, dry, fix, g, } \\
\text { shut, though, wet }\end{array}$} \\
I (pronoun) & See, shut, sit \\
No (negation) & Bed, down, fix, home, plug, water, wet \\
See (request) & Baby, pretty \\
More (quantity) & Car, cereal, cookie, juice, toast, high, hot, \\
Hi (greeting) & walk \\
Other & Mama, papa \\
My (possesion) & Bib, bread, milk, paint, piece, pocket, \\
& shirt, side, light, pants, skirt, shoe, water \\
\hline
\end{tabular}

Sumber:(http://books:google.co.id/books?id=ujobaMPP81C\&P9=PA2932ipg=PA293\&dq=pivot+ grammar+oleh+brain\&source=KRTdUFXA2\&sig=decx_Rg5ruvFF8RYIGK_XOUS

Anak pada usia dua tahun selalu menggunakan pivot grammar yang terdiri dari pivot dan Open Class. Yang dimaksud dengan open class adalah seperangkat kata (kelas kata) yang berisikan sejumlah bentuk yang tidak terbatas. Kata benda, kata kerja, kata sifat dan kata keterangan adalah kata open class yang selalu digunakan oleh anak. Kata-kata baru dapat ditambahkan kepada kelas ini, contoh, kata laser, e-commerce, chatroom. Sebaliknya Closed Class seperti konjungsi, preposisi, kata ganti orang, kata kerja bantu, infleksi sangat jarang digunakan oleh anak (Longman Dictionary, 2002: 374).

Braine dalam McNeil (1970:25) juga mengatakan bahwa pemerolehan bahasa anak menggunakan struktur pivot sebagai berikut:

$$
\begin{array}{ll}
\mathrm{P} 1+\mathrm{O} & \text { (Pivot1 +Open) I sleep, , I make, I shoe } \\
\mathrm{O}+\mathrm{P} 2 & \text { (Open + Pivot2)nini come } \\
\mathrm{O}+\mathrm{O} & \text { (Open + Open) one shoe } \\
\mathrm{O} & \text { (Open) beatiful }
\end{array}
$$

Menurut Gleason (1998:366), ujaran dua-kata cendrung sama dengan ujaran satu kata, misalnya mengatakan bentuk negatif "no" yang berarti "no bed" dan mommy...lunch yang berarti "mommy is eating lunch".

\section{Tahap Penyerupai Telegram (telegraphic speech)}

Apabila seorang anak sudah mampu menggunakan lebih dari dua kata, maka jumlah kata yang dipakai dapat mencapai tiga, empat bahkan lebih. Pada usia dua tahun, anak sudah mulai menguasai "kalimat-kalimat" yang lebih lengkap. Hubungan-hubungan sintaktik (grammatical relations) sudah mulai tampak dengan jelas, tetapi mereka masih sulit menggunakan kata fungsi seperti preposisi, afiks infleksional, kata kerja bantu, dan determiner. Contoh, what that, daddy like book, cathy build house, no sit here. Ujaran ini disebut telegrafik karena layaknya orang mengirim telegram yang mementingkan makna dari pada struktur. Pada usia ini, anak sulit menggunakan finite verbs (Badford 1996: 54), mereka selalu menghilangkan orang ketiga tunggal dalam kalimatnya, contoh: Paula play with ball, tidak 
menggunakan kata kerja bantu, contoh: Baby talking, Daddy gone, dan tidak menggunakan infinitive to, contoh: Want go out.

\section{Peniruan}

Peniruan dalam berbahasa adalah salah satu strategi yang dipakai anak dalam

pemerolehan bahasa. Kesimpulan secara umum dipercaya. Peniruan secara berulang-ulang merupakan strategi penting dalam pembelajaran bahasa dan aspek penting penguasaan fonologi pada usia dini. Peniruan sejalan dengan prinsip-prinsip pemerolehan bahasa menurut kaum behavioris prinsip-prinsip yang relevan pada tahap awal.

Menurut kaum behavioris, peniruan ditingkat lebih dalam jauh lebih penting dalam proses pemerolehan bahasa. Tipe peniruan struktur permukaan ini terjadi dimana orang mengulang-ulang atau menirukan struktur permukaan, lebih memperhatikan kode fonologis ketimbang kode semantik.

Pada tahap paling dini pemerolehan bahasa anak-anak memunculkan banyak sekali peniruan karena bayi belum menguasai kategori-katagori semantik untuk "memaknai ujaran". Tetapi ketika anakanak merasakan pentingnya makna (semantik), mereka akan memberi banyak perhatian pada tataran semantik yang penuh makna yaitu struktur dalamnya. Bahkan, peniruan struktur dalam ini bisa benarbenar menghalangi perhatian mereka pada struktur permukaan sehingga mereka akan tampak sebagai peniru yang buruk. Contoh percakapan yang direkam oleh McNeill 1966 ( dalam Brown (2007: 47).

Anak: No body don't like me

Ibu : No, say "nobody likes me"

Anak: Nobody don't like me (saling berdebat ini berulang delapan kali)

Ibu : No, now listen carefully; say "nobody likes me"

Anak: Oh! Nobody don't likes me.

Dalam percakapan di atas terlihat bahwa ibu terpaku pada urusan gramatikal permukaan teknis, sedangkan anaknya berusaha mendapatkan semacam nilai makna dalam berkomunikasi.

\section{HASIL TEMUAN DAN PEMBAHASAN}

Berikut ini dapat dilihat ujaran satu kata, dua kata dan tiga kata (termasuk pivot grammar) yang dilakukan oleh Francesca dalam percakapannya dengan ibu, kakak, dan babby sitter di rumah.

\section{Percakapan 1:}

$\begin{array}{ll}\text { Anastasia } & : \text { Mommy, I talk? } \\ \text { Mother } & : \text { No, It's for Francesca to talk to her teacher. } \\ & \text { Yah, you can talk (Francesca) } \\ \text { Francesca } & : \text { Yup. } \\ \text { Mother } & : \text { No, you can't hear anything. } \\ \text { Francesca } & : \text { Yup. } \\ \text { Mother } & : \text { Yup? What's for the 'yup'? } \\ \text { Francesca } & : \text { Fh fh (blow the tape) } \\ \text { Mother } & : \text { No, no, you don't need to blow into it } \\ \text { Dari percakapan di atas terlihat Francesca telah menggunakan satu kata yaitu kata "yup". }\end{array}$

\section{Percakapan 2:}

Francesca : Chicken

Wiwi : And this one?

Francesca : Horse.

Wiwi : What?

Francesca : Horse

Wiwi : And this one?

Francesca : Cow.

Wiwi : What? Cow. And this one? 
Francesca : Baa-baa.

Wiwi : Lamb.

Dari percakapan di atas terlihat Francesca telah menggunakan satu kata yaitu kata "horse”, ”cow”, dan

"baa-baa". Belum ada ujaran dua kata dalam percakapan ini.

\section{Percakapan 4:}

Ibu Martini : Come on Chika, you talk.

Francesca : All sock.

Ibu Martini $\quad$ : Ya.

Francesca : No ssh.

Ibu Martini : Mossy? Not mossy.

Dari percakapan di atas terlihat Francesca telah menggunakan pivot grammar yaitu "all sock"

\section{Percakapan 5:}

Anastasia : Mom, can you help me?

Francesca : Please.. please.. my flower.. my..

Dari percakapan di atas terlihat Francesca telah menggunakan bentuk pivot grammar yaitu "my flower".

\section{Percakapan 6:}

Mother : Where did you go? Where did you go?

Francesca : Ugh.. the.. fall.. the fall.. my baby.. fall.. ah fall.. ah baby fall.. a fall.. Mommy!..

Mother : Okay Francesca, what happens to the baby?

Francesca : Baby down.

Mother : The baby fell down?

Anastasia : From the bed

Mother : No

Anastasia $\quad:$ Yep

Anastasia : : And it have bit sakit and it have her bleeding on her knee

Mother : Really? Oh okay.

Francesca : This Anast

Dari percakapan di atas terlihat Francesca telah menggunakan tiga buah pivot grammar yaitu my baby, baby fall, baby down. Pivot grammar yang pertama "my baby" mengacu kepada "to her baby doll". Sesuai dengan teori pivot grammar oleh Braine, Francesca telah dapat menggunakan struktur kombinasi $\mathrm{P} 1+\mathrm{O}$ "my (pivot) + baby (open)". Ia juga telah dapat menggunakan bentuk O (open) + O (open) dalam "this Anast" yang artinya this is for you, Anast.

\section{Percakapan 7:}

Mother

: Have your dinner then Francesca

Francesca

: No yucky

Mother

: It's yucky Francesca. It's lovely

Ibu Martini

: Come on Chika. Look lion Chika

Mother

: Yes, come and see the lion. Francesca, go and eat your dinner, please. It's not even hot.

Francesca Francesca.... Francesca can you go and eat your dinner, please

Mother : Yes. No, this is mine. Give that back to me, please. Thank you.

Dari percakapan di atas Francesca telah menggunakan pivot grammar P1 + O "No yucky" yang berarti No, it is yucky. Kata "No" adalah pivot sedangkan "yucky" adalah open word.

\section{Percakapan 8:}

Mother : So, Francesca.. Wow, that's a good girl Anastasia 
Francesca : Uch.. baby.. I jump

Mother : You were jumping in the baby's bed?

Francesca : Yes. Nice Nini? (to Ibu Martini about the food)

Mother : Yes, its nice

Dari percakapan ini Francesca telah menggunakan pivot grammar P1 + O "I jump" yaitu pivot word adalah "I" dan "jump" adalah open word.

\section{Percakapan 9:}

Anastasia $\quad$ : Mommy do it, do it, do, it..

Francesca $\quad$ : I jump. in a bed.

Sorry.. my monkey.. err sei.. love baby

Mother : You're little monkey. You're mommy's baby, aren't you?

Francesca : My baby.. my fall.

Mother : Okay, can you sit down and eat your dinner please, Francesca?

Dari percakapan ini Francesca telah menggunakan pivot grammar P1 + O "I jump" yaitu pivot word adalah "I" dan "jump" adalah open word, begitu juga dengan "my monkey, love baby, my fall". Pada percakapan ini Francesca telah menggunakan ujaran tiga kata "in a bed".

\section{Percakapan 10:}

Wiwi : Chika, pant.

Francesca : No, no pant.. oh.. no.. (crying).. no, Huh

Ah, no pant.. (crying)

Wiwi : How about this one? Flower?

Francesca : No

Dari percakapan ini Francesca telah menggunakan pivot grammar P1 + O "No pant" yaitu pivot word adalah "No" dan "pant" adalah open word.

\section{Percakapan 11:}

Mother : So, what are you doing?

Francesca : I book

Mother : a book?

Do you have your breakfast now? Mm, Francesca? Sorry?

Francesca?

Dari percakapan ini Francesca telah menggunakan pivot grammar P1 + O "I book" yaitu pivot word adalah "I" dan "book" adalah open word. Di sini I book berarti "I need a book".

\section{Percakapan 12:}

Mother : What'd you got?

Francesca : I got

Mother : What you got?

Francesca : I got

Mother : You got what? You got the fly?

Francesca : $\mathrm{Ya}$

Mother : Yes? Okay. Francesca, can you sit down please?

Francesca : Oooo?

Mother : Oow

Dari percakapan ini Francesca telah menggunakan pivot grammar P1 + O "I got" yaitu pivot word adalah "I" dan "got" adalah open word. Pada percakapan ini Francesca hanya menjawab I got saja meskipun ibunya beberapa kali bertanya kepadanya. 


\section{Percakapan 13:}

Francesca : See..

Anastasia : See.

Francesca : Anast.

Ibu Martini : See..

Francesca $\quad$ : See.. I making.. I.. making? I making..

Ibu Martini : Chika making?

Francesca : I make..

Dari percakapan ini Francesca telah menggunakan pivot grammar P1 + O "I making" yaitu pivot word adalah "I" dan "making" adalah open word juga I make. Terlihat memang pada usia ini anak belum dapat menggunakan tense yang benar.

\section{Percakapan 14:}

Francesca : Ah, open.

Ibu Martini : What open?

Francesca $\quad$ : Open.. my sh.. what.. Aaah (fall down), aaah sakit.. (crying)

Dari percakapan ini Francesca telah menggunakan pivot grammar dengan menggunakan O " open" dan "sakit" (bahasa Indonesia).

\section{Percakapan 15:}

Wiwi :

Francesca

Wiwi : What is that?

Francesca : My toe.

Wiwi : That?

Francesca : That teddybear.

Dari percakapan ini Francesca telah menggunakan pivot grammar $\mathrm{P} 1+\mathrm{O}$ "my tummy" yaitu pivot word adalah "my" dan "tummy". Disamping ini terlihat juga Francesca sudah dapat mengucapkan pivot grammar"That teddybear".

\section{Percakapan 16:}

Ibu Martini : Come on Chika, you talk.

Francesca : All sock.

Ibu Martini : $Y a$.

Francesca : No ssh.

Ibu Martini : Mossy? Not mossy.

Dari percakapan ini Francesca telah menggunakan pivot grammar P1 + O "all sock" yaitu pivot word adalah "all" dan "sock".

\section{Percakapan 17:}

Anastasia : Mom, can you help me?

Francesca : Please.. please..

my flower.. my..

Dari percakapan ini Francesca telah menggunakan pivot grammar $\mathrm{P} 1+\mathrm{O}$ "my flower" yaitu pivot word adalah "my" dan "flower". 


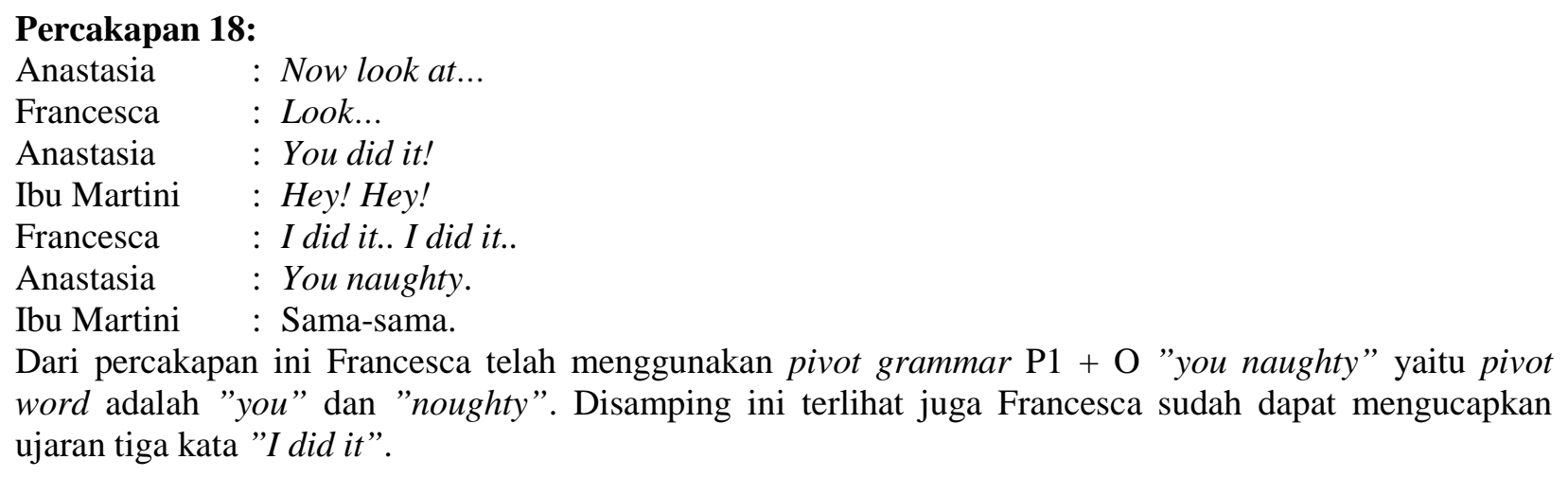

\section{Percakapan 19:}

Anastasia : Ibu, that is for...for...like this

Ibu Martini : It's broken already. It's not... Already broken.

Anastasia : It's like this, Ibu. Now coloring like this, Ibu... but I need, Ibu

Francesca : Na...na... Nini come...

Anastasia $\quad$ : I need, Ibu

Ibu Martini : : Already broken.

Dari percakapan ini Francesca telah menggunakan pivot grammar O+ P2 "nini come". "Nini" adalah open word dan "come" adalah P2 (final pivot). Sesuai konteks percakapan "Nini come" bermakna Nini, come here. Disamping ini terlihat juga Francesca sudah dapat mengucapkan ujaran tiga kata, berupa kalimat "I need Ibu".

\section{Percakapan 20:}

Francesca : Horsie... horsie... bye-bye horsie... horsie... heorsie... bye-bye

Mother : Where are you going?

Francesca : I go horsie

Mother : You're going horsie Okay, you like horses.

Fracesca : Bye-bye

Dari percakapan ini Francesca telah menggunakan pivot grammar P1 + O "bye horsie" yaitu pivot word adalah "bye" dan "horsie". Disamping ini terlihat juga Francesca sudah dapat mengucapkan ujaran tiga kata "I go horsie".

\section{Percakapan 21:}

Francesca $\quad$ : My damit, my monkey, my toulet, my ice, my sock, my sock, my sock, my damit. Dari percakapan ini Francesca telah menggunakan pivot grammar P1 + O "my damit, my monkey, my toulet, my ice, my sock, my sock, my sock”.

\section{Percakapan 22:}

Francesca $\quad$ : (singing Twinkle-twinkle little stars with Ibu Martini) No sock.. Stop it

Ibu Martini : Sing! I love you, you love me... (Barney song)

Francesca : Singing... Barney song

Dari percakapan ini Francesca telah menggunakan pivot grammar $\mathrm{O}+\mathrm{O}$ " no sock" dan pivot grammar "stop it".

\section{Percakapan 23:}

Mother : Anast, please. Let her have her dinner. 
Francesca $\quad$ : My house... mama house (mommy, my house!)

Mother : Anast.!

Francesca : House.. (crying)

Mother : Anastasia, stop it!

Anatasia : I'm making a house.

Mother : Ya, but stop being wrecked..

Dari percakapan ini Francesca telah menggunakan pivot grammar P1 + O "my house" dan "mama house" yaitu pivot word adalah "my" dan open house "house" yang berarti mommy, my house.

\section{Percakapan 24:}

Mother : What are you doing, Francesca? What are you doing, Francesca?

Ha? Francesca, what are you doing?

Francesca : I crayon

Mother : Coloring?

Francesca : Yah

Anastasia : Hey! Where is my...

Ibu Martini : What?

Anastasia : My measure

Mother : It's not a measure. That's a ruler.

Francesca : I crayon... crayon..

Mother : You coloring?

Francesca : I crayon.. crayon...

Mother : You coloring?

Anastasia : I need a frame. Ya, I got my.. but

Francesca : I crayon

Ibu Martini : You crayon

Anastasia : Mommy, do you like brown flowers?

Mother : $Y a$

Dari percakapan ini Francesca telah menggunakan pivot grammar P1 + O "I crayon" beberapa kali, meskipun ibu dan kakaknya beberapa kali bertanya kepadanya tetapi Francesca tetap menjawab dengan dua kata yang sama "I crayon".

\section{Percakapan 25:}

Francesca $\quad$ : I make... I make... I make.. I make... All make..

I shoe,,, I floor... No! No!

Ibu Maryini : Look! Cartoon! Look...

Francesca $\quad:$ No! No! No!

Anastasia $\quad$ : Ibu, look.. Ibu, look.. See

Dari percakapan ini Francesca telah menggunakan pivot grammar P1 + O "I make", "All make".

\section{Percakapan 26:}

Francesca : Mommy..

Mother : Yes, Francesca.

Francesca : I sakit

Mother : No, it's not sakit. Sunburn.

Francesca : No sakit?

Mother $\quad:$ No, it's not sakit, Francesca

Francesca : Habi?

Mother : It's not sakit 
Francesca : Habi?

Mother : No, it's sunburn

Francesca : Ha?

Mother : It's from the sun.

Francesca : Whaa?

Mother : Sun, ya.

Dari percakapan ini Francesca telah menggunakan pivot grammar P1 + O "I sakit" "no sakit". Pivot Grammar "I" dan "no" sedangkan Open Word "sakit". Francessca menggunakan satu kata bahasa Indonesia "sakit".

\section{Percakapan 27:}

Francesca : Mmmm? No this. Coklat [chocolate]

Wiwi : Aaah chocolate. Chika like it? Chika like chocolate?

Francesca : No

Wiwi : $Y a$

Francesca : Coklat!! [chocolate]

Wiwi : Chocolate

Francesca : No.. I say coklat!! [=chocolate]

Wiwi : Cokat!!!

Dari percakapan ini Francesca telah menggunakan pivot grammar P1 + O "No this". Pivot Grammar "No" dan Open Word "this", yang sesuai konteks kalimat ini bermakna I don't want this food. Francesca juga dapat mengucapkan tiga kata " I say coklat".

\section{Percakapan 28:}

$\begin{array}{ll}\text { Francesca } & \text { : Bye-bye mommy } \\ \text { Mother } & \text { : Bye-bye sweetie } \\ \text { Francesca } & \text { : Bye-bye mommy } \\ \text { Mother } & \text { : See you } \\ \text { Anastasia } & \text { : Bye mama } \\ \text { Francesca } & \text { : Bye-bye mama } \\ \text { Anastasia } & : \text { I want hug } \\ \text { Francesca } & \text { : I hug }\end{array}$

Dari percakapan ini Francesca telah menggunakan pivot grammar $\mathrm{P} 1+\mathrm{O}$ "bye bye mama (mommy)" dan "I hug". Pivot Grammar "bye bye dan "I", sedangkan Open Word ada pada kata "mama dan hug".

\section{PEMBAHASAN}

\section{Ujaran Dua Kata: Umur Dua tahun}

Selaras dengan teori pemerolehan bahasa pada anak, penguasaan sintaksis berlangsung secara bertahap: satu, dua kata, dan tiga kata atau lebih. Dalam Bahasa Inggris ujaran satu kata (one word utterance) adalah sama dengan ujaran satu suku karena bahasa Inggris pada umumnya adalah dwi suku bahkan poli suku. Pada umur dua tahun, Francesca sudah dapat berbicara dengan baik, disamping itu juga ada satu bahasa Indonesia yang dapat ia ucapkan yaitu kata "sakit".

\section{Bentuk Negatif}

Dalam bahasa Indonesia bentuk negatif dapat diucapkan dengan bukan, tidak, belum, dan jangan. Fracesca menggunakan kata "no" untuk mengatakan "bukan" atau "tidak mau" seperti percakapannya di bawah ini: 


\section{Percakapan 10:}

Wiwi

: Chika, pant.

Francesca $\quad$ : No, no pant.. oh.. no.. (crying).. no, Huh Ah, no pant.. (crying)

Wiwi : How about this one? Flower?

Francesca : No

Dalam percakapan di atas, kata "no, no pant (crying) ..no huh ..ah no pant (crying)" menunjukkan penolakan.

\section{Percakapan 7:}

Mother : Have your dinner then Francesca

Francesca : No yucky

Mother : It's yucky Francesca. It's lovely

Ibu Martini : : Come on Chika. Look lion Chika

Mother : Yes, come and see the lion. Francesca, go and eat your dinner, please. It's not even hot. Francesca.... Francesca can you go and eat your dinner, please

Francesca : No

Dalam percakapan ini Francesca menolak ajakan ibunya makan malam dengan kata "no"

\section{Percakapan 27}

Francesca : Mmmm? No this. Coklat [chocolate]

Wiwi : Aaah chocolate. Chika like it? Chika like chocolate?

Francesca : No

Wiwi : Ya

Francesca : Coklat!! [chocolate]

Wiwi : Chocolate

Francesca : No.. I say coklat!! [=chocolate]

Dalam percakapan ini Francesca menolak pemberian pembantunya dengan kata

"no coklat"

Bentuk negatif "no" yang berarti menolak atau jangan merupakan unsur dalam kalimat imperatif negatif. Kata ini sering muncul sebagai bentuk tunggal dalam suatu larangan dan pada umumnya berada pada awal kalimat seperti contoh di atas No, I say coklat, maka penguasaannyapun merupakan penguasaan bentu leksikal yang terpisah.

\section{Struktur Modifikasi}

Kemampuan sintaksis Francesca sudah dapat terlihat pada struktur modifikasi yaitu pada bentuk posesif dan deskriptif.

Pada frasa posesif terdapat pada:

$$
\begin{aligned}
& \text { my flower } \\
& \text { my baby } \\
& \text { my monkey } \\
& \text { my horse } \\
& \text { my damit } \\
& \text { my ice } \\
& \text { my sock }
\end{aligned}
$$

Pada frasa deskriptif terdapat pada: 
baby fall

baby down

love baby

\section{Pronomina}

Pronomina yang telah dikuasai Francesca baru pada kata ini dan itu, seperti pada percakapan di bawah berikut.

\section{Percakapan 6:}

Mother : Where did you go? Where did you go?

Francesca : Ugh.. the.. fall.. the fall. my baby.. fall.. ah fall.. ah baby fall.. a fall.. Mommy!..

Mother : Okay Francesca, what happens to the baby?

Francesca : Baby down.

Mother : The baby fell down?

Anastasia : From the bed

Mother : No

Anastasia : Yep

Anastasia : And it have bit sakit and it have her bleeding on her knee

Mother : Really? Oh okay.

Francesca : This Anast

Kata "This Anast" yang digunakan oleh Franceca untuk menunjukkan pronomina persona.

\section{Percakapan 15:}

Wiwi : What is that?

Francesca : My tummy.

Wiwi : What is that?

Francesca : My toe.

Wiwi : That?

Francesca : That teddybear.

Kata "That teddybear" yang digunakan oleh Franceca untuk menunjukkan pronomina person

\section{PENUTUP}

\section{Simpulan}

1. Penguasaan sebuah bahasa oleh anak dimulai dari pemerolehan bahasa pertama. Pemerolehan bahasa merupakan sebuah proses yang sangat panjang sejak anak belum mengenal sebuah bahasa sampai fasih berbahasa.

2. Peranan orang tua, kakak, adik, dan lingkungan sangat mempengaruhi pemerolehan bahasa anak. Apabila dalam proses awal menunjukkan pemahaman dan pengasilan yang baik dari keluarga dan lingkungan bahasa yang diperolehnya, proses pemerolehan bahasa selanjutnya akan mendapatkan kemudahan. Tahapan-tahapan berbahasa ini berpengaruh besar pada proses pemerolehan bahasa anak.

3. Pemerolehan anak umur 2 tahun telah mampu mengucapkan ujaran dua-kata dan tiga-kata. Hampir 95\% ujaran dua kata (pivot grammar) yang diucapkan Francesca terdiri dari P1 + O yaitu contoh pada my baby, no yucky, I got, "my damit, my monkey, my toulet, my ice, my sock, my sock, my sock" sisanya $5 \%$ terdiri dari $\mathrm{O}+\mathrm{P} 2$ pada kata "nini come", dan $\mathrm{O}+\mathrm{O}$ pada kata "no 
sock". Di samping itu, Francesca telah dapat menggunakan ujaran tiga kata "I say coklat", "I did it", "I go horsie". Ini tidaklah berarti bahwa semua anak mendapatkan pemerolehan bahasa yang sama karena pemerolehan bahasa anak bersifat unik bergantung pada lingkungannya.

4. Anak telah dapat membuat bentuk negatif "no", struktur modifikasi yang terdiri atas frasa posesif (my flower, my monkey, my baby), frasa deskriptif (baby fall, baby down, love baby), pronomina ini (this Anast) dan pronomina itu (that teddybear).

\section{Saran}

Lingkungan sangat mempengaruhi pemerolehan bahasa anak sehingga peran aktif lingkungan yang positif dalam berbahasa akan membawa dampak positif pada bahasa si anak. Orang tua sebaiknya mendampingi anak di dalam pertumbuhannya. Oleh sebab itu diharapkan keluarga dapat membantu mengembangkan pemerolehan bahasa anak dengan mendampingi anak berkomunikasi agar pemerolehan bahasanya menjadi lebih baik. 


\section{DAFTAR PUSTAKA}

Brown, Douglas. 2007. Prinsip Pembelajaran dan Pengajaran Bahasa, Edisi Kedua. Jakarta: Pearson Education.

Chomsky, Noam. 1957. Syntactic Structure. Paris: The Hague Mouton.

Chaer, Abdul. 2003. Psikolinguistik: Kajian Teoretik. Jakarta: PT Rineka Cipta.

Clark, Eve V. 2003. First Language Acquisition. New York: Cambridge University Press.

Dardjowidjojo, Soenjono, 2000. Echa: Kisah Pemerolehan Bahasa Anak Indonesia. Jakarta: PT Gramedia Widiasarana Indonesia.

Gleason, Jean. Berko dan Ratner, Nan. Bernstein. Editor. 1998. Psycholinguistics. Second Edition, Fortworth Texas: Harcourt Brace College Publisher.

McNeill, David. 1970. The Acquisition of Language: Method, Description, and Explanation. New York: Cambridge University Press.

Richards, Jack C.,2000. Dictionary of Language Teaching \& Applied Linguistics. Third Edition. London: Longman Group.

Slobin dan Saac. 1979. Psycholinguistic. Second Edition. United Stated: Lpngman Haigher Education.

Steinberg, Danny D. 1993. An Introduction To Psychotion linguistics. U K: Longman Limited Group..

http://books:google.co.id/books?id=ujobaMPP81C\&P9=PA2932ipg=PA293\&dq=pivot+grammar +oleh+brain\&source=KRTdUFXA2\&sig=decx_Rg5ruvFF8RYIGK_XOUS

(diakses 15 November 2016). 